\title{
Research on the Value and Model of Cultural Creative Product Design Workshop in Colleges and Universities
}

\author{
$\mathrm{Xi} \mathrm{Yan}{ }^{1, *}$ \\ ${ }^{1}$ School of Art and Design, Fuzhou University of International Studies and Trade, Fuzhou, Fujian, China \\ *Corresponding author. Email: wyxxtla@yeah.net
}

\begin{abstract}
The cultural and creative products of colleges and universities embody the connotation of their spiritual civilization. By analyzing the value and deficiency of cultural creative products in colleges and universities, this paper puts forward the necessity of design workshops for cultural creative products in colleges and universities, and formulates design strategies and business models. Teachers and students of each major form a small team integrating market research, design, marketing, management and other departments to bring new vitality and market for cultural and creative products of colleges and universities by virtue of the advantages of independent design and development of teachers and students.
\end{abstract}

\section{Keywords: colleges and universities, cultural creativity, design workshops, products}

\section{INTRODUCTION}

Since the development of the industrial revolution, benefiting from the convenience brought by mechanized large-scale production, a variety of massproduced goods have occupied all aspects of people's life, providing people with tools to meet various life needs. However, it is these "cold" commodities that make people feel tired and aesthetic fatigue for industrial products that can only satisfies functional needs. Cultural and creative industries, by giving cultural attributes and emotional factors to existing industries, make ice-cold appliances full of vitality. Cultural and creative design makes products in daily life realize the transition from "effective" to "interesting". Today, China is vigorously developing its cultural and creative industries. The launch of a series of cultural and creative products by the Palace Museum and the contest of large and small cultural and creative products all show that cultural and creative industry is becoming an increasingly important economic field. The 21 st century is an era of knowledge economy and aesthetic economy.

\section{DEFINITION OF THE DESIGN CONCEPT OF CULTURAL CREATIVE PRODUCTS IN COLLEGES AND UNIVERSITIES}

Compared with ordinary products, cultural and creative products should not only have economic value, but also contain cultural and creative value. The cultural and creative products of colleges and universities take the accumulation of natural resources as the core, combine the unique historical and cultural elements of colleges and universities, conduct targeted and classified cultural combing and gene extraction, create cultural and creative sequence, and develop popular image products. [1] College cultural creative products stand out from the general cultural creative products. It can not only take the unique campus culture as the design resource, but also reproduce the local historical and cultural elements with the help of cultural and creative products. Meanwhile, it cultivates excellent cultural and creative teams for colleges and universities, thus providing platforms and opportunities for students' professional practice.

\section{LIMITATIONS OF CULTURAL CREATIVE DESIGN WORKSHOPS IN COLLEGES AND UNIVERSITIES}

By collecting and sorting out the existing cultural and creative products in domestic universities, it can be found that the existing cultural and creative products are seriously homogeneous. Most of the patterns, such as school logo or school emblem, are printed to stationery such as notebooks and bookmarks, which are not attractive enough to consumers and thus lack of dissemination. The reasons for such phenomenon are as follows. First, most of the products are designed by individuals or off-campus enterprises. The designers fail to have a deep understanding of traditional culture and the school philosophy and campus culture, which makes the designed products unable to reflect the cultural characteristics and campus spirit. Second, designers fail to think about product positioning from the perspective of schools and consumers, and fail to classify the functions. As a result, the products are 
single and the audience is small, and the customer group is basically teachers, students and alumni. The products are less appealing to other groups that don't know much about the school Generally speaking, most of the existing cultural and creative products in colleges and universities are not systematic, and there are no standardized teams in terms of design and marketing, failing to give play to the due role of cultural and creative products in colleges and universities.

\section{VALUE OF CULTURAL CREATIVE DESIGN WORKSHOPS IN COLLEGES AND UNIVERSITIES}

Cultural and creative products of colleges and universities are carriers of campus culture. The trading of cultural and creative products in the market makes the explicit culture (such as architecture) and implicit culture (such as school motto) of colleges and universities spread more widely, and provides a more effective way to establish the brand image of cultural and creative products in colleges and universities. At the same time, the unique local culture, such as architecture, folk customs, art and other elements, and more practical and interesting product forms are integrated to play a positive role in the protection and promotion of culture. Specifically, the establishment of cultural and creative design workshops in colleges and universities enjoys the following values:

\section{A. Artistry and culture}

Colleges and universities bring together teachers and students from all over the world, which makes the diverse cultural connotation converges here. The establishment of cultural creative design workshops in colleges and universities provides an opportunity for cultural collision and fusion. Teachers and students with different cultural backgrounds participate in the research and development and design of cultural creative products, which can give diversified artistic characteristics to the products. The jumping thinking of the young college students adds lively temperament to the design, thus improving the artistic value of the product.

Culture is the soul of cultural creative products, not products derived from campus culture or cultural creative products, but "souvenirs". The establishment of cultural and creative design workshops in colleges and universities is based on the design and creation of teachers and students. Their cognition of campus culture is more profound than that of off-campus personnel, and their extraction and application of cultural concepts are more in line with the needs of cultural and creative products of the university.

\section{B. Dissemination}

The dissemination of college culture is based on the circulation of cultural and creative products. Only by selling the products can the dissemination effect be achieved. By engaging students in the design of cultural and creative products, students can better understand the needs of the design objects (consumers), so that the products can serve consumers more specifically and meet their needs. In this way, the sales of cultural and creative products can be raised and the spread of campus culture can be promoted.

\section{Improving students' sense of innovation}

By participating in the design of the school's cultural and creative products, students' sense of innovation can be greatly improved. Learning is not only about learning knowledge, but also about using knowledge. True knowledge comes from practice. Under the guidance of teachers, students can learn the design methods of cultural and creative products by participating in the design process, improve creative thinking, and lay a solid foundation for later study and work.

\section{Cooperation with enterprises is more conducive to the application of knowledge}

Although the educational resources of higher education have become more and more comprehensive, in general, higher education is still relatively closed. Experience is the mother of wisdom. The establishment of cultural and creative design workshops on campus enables students to truly participate in the actual work process. Cooperation with enterprises enables students to fully understand the application of design methods and to find solutions to the contradictions between theory and practice, so as to help students to be less confused and better at problem-solving after entering the society, and adapt to the society more quickly.

\section{E. Providing students with entrepreneurial opportunities}

Opinions of the General Office of the State Council on Deepening the Reform of Innovation and Entrepreneurship Education in Institutions of Higher Learning (Guo Fa [2015] No. 36) pointed out that, "Deepening the reform of innovation and entrepreneurship education in institutions of higher learning is an urgent need for China to implement the strategy of innovation-driven development and promote the quality, efficiency and upgrading of the economy. It is also an important measure to promote the comprehensive reform of higher education and promote higher quality entrepreneurship and employment of college graduates. The 18th National Congress of the Communist Party of China made important arrangements for training innovation and entrepreneurship talents, and the State Council set clear requirements for strengthening innovation and entrepreneurship education." 
Cultural and creative product design has become the norm. Undoubtedly, cultural creative design workshops in colleges and universities provide an effective and convenient channel for students to start their own businesses. Cultural and creative design studio can be regarded as a small start-up company. Product research and development, product sales, and the division of labor and cooperation in workshops can help students with different majors to find suitable positions and form a complete entrepreneurial team.

\section{THE DESIGN STRATEGY AND}

\section{MANAGEMENT MODE OF CULTURAL CREATIVE PRODUCT DESIGN WORKSHOP IN COLLEGES AND UNIVERSITIES}

\section{A. Building brand image}

Unique brand image is the key to distinguish products from the market. In the current situation of serious homogenization, brand can undoubtedly simulate consumers' purchasing desire. For example, the Cultural and Creative Activities of the Palace Museum was founded in 2008 by the Cultural and Creative Center of the Palace Museum. In August 2013, the Palace Museum in Beijing held its first cultural innovation and design competition with the theme of "Bringing the Palace Museum Culture Home". Since then, the Palace Museum has gradually built a young and fashionable creative industry chain with "cute" products as the mainstream brand, covering all aspects of life from stationery to cosmetics. Among them, the IP image of "Forbidden City Cat" is more deeply rooted in people's hearts, making serious history more close to the public. (See "Fig. 1" and "Fig. 2")$$
\text { 合 来自故宫的礼物 }
$$

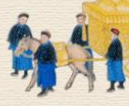

Fig. 1. The banner of the "Palace Museum in Taobao".

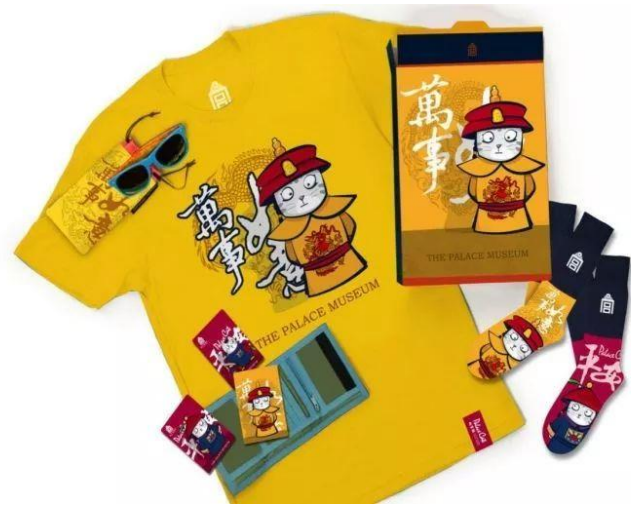

Fig. 2. Cultural and creative products related to "the Cat of the Palace Museum".

\section{B. Clearing $R \& D$ and production process}

Clear product research and development process is the key for college cultural creative product design workshops to maintain stable output and ensure product design quality for a long time. In terms of product design, the well-known design consulting firm IDEO has put forward the design thinking with demand understanding, problem definition, divergent thinking, prototype design and model iteration as the main steps. According to the actual environment of the cultural and creative product design workshop in universities, it can be transformed into the following steps:

1) Preliminary research and product classification: Through questionnaire survey, field observation, network survey and other methods, the statistical data of consumers' portraits and the product types they like are collected as the basis for product classification and positioning.

Cultural and creative products can be classified according to different functions of cultural and creative products in colleges and universities and the positioning of consumer groups. It can be divided into school gift, presents for friends, souvenir and other categories. The functions and forms of products of different categories are different, and the cultural connotations selected are also different. Specific information is as follows.

a) School gift: As the "name card" of the school, if the gift is given to other schools or distinguished guests, the material with high economic value should be selected to improve the value of the product itself. The school's educational philosophy and motto should be taken as the main cultural source to reflect the unique cultural value of the school.

b) Presents for friends: The gifts are mainly consumed by alumni, school-enterprise cooperation companies, etc. The cultural value of the product can be extracted from the local unique history and culture, the architecture of the school, the environment or some special things that can recall the memory. On this basis, practicality can be increased, so that consumers can not only use the product as a daily necessities, but also arouse emotional connection.

c) Souvenirs: Most of the souvenirs are consumed by teachers and students or parents of students on campus. The motive for purchase is mainly to keep commemorations. In addition to badges, postcards, mouse pads, card bags and other products, it can also cover more lively and interesting products that can attract young people, such as figures dolls representing different professional characteristics of the school and models of school buildings.

2) Sketch stage and solid design: After the classification of products and the selection of materials 
and cultural sources, the design studio can enter into the sketching stage. At this stage, the research and development of cultural creative products is a combination of practicality, fashion and culture. By combining modern people's indispensable functional products with the carrier of traditional culture, cultural creativity products conforming to the current concept of life can be generated, and young people's attention to local culture and campus cultural creative products can be aroused, and then their interest in local culture and campus culture can be generated.

In the aspect of model making, the pattern, structure and material of the product should have specific different schemes. The design team, the manufacturer and the sales team discuss together to choose the best solution for the physical design. The 3D design software such as rhinoceros and C4D will be employed to draw the effect diagram of the selected scheme, and then the prototype of the product will be obtained according to the effect diagram. The team will discuss and improve the prototype. This process may be repeated several times before completing the product.

3) Production: The design team should discuss the material and cost issues with the manufacturer during the design phase to avoid production difficulties, high cost, and mass production. Workshops should also set up a team responsible for production-related matters to coordinate issues such as design and production, cost and transportation.

\section{Developing management and marketing strategies}

The marketing team of cultural and creative design workshops in colleges and universities should formulate brand marketing strategies and choose different marketing strategies for different categories of products through online, offline, on-campus and off-campus marketing channels. As publicity media, weibo, WeChat and other social platforms export the cultural and economic values of brands and products to the audience, hoping to attract more consumers.

Since the members of the cultural and creative design workshop are all students and lack of social experience and capital investment, the establishment of school-enterprise cooperation mechanism can not only help the team solve the problems encountered in the entrepreneurial process and provide practical work experience, but also increase the design funds to realize the final product.

Similar to the management departments in enterprises, the management team of the cultural and creative design workshop in colleges and universities should communicate with the enterprises cooperating with universities in the early stage of design and negotiate the ratio of expenditure and income. The time and funds of the three departments of design, production and marketing can be arranged as a whole so that the three parts can complete the assigned work to the maximum extent and form a coordinated and efficient work system.

\section{CONCLUSION}

Cultural and creative products of colleges and universities are the carrier of campus spiritual culture, which represents the image of the school. At the same time, cultural and creative products should enjoy high economic value, so it is necessary to design products with complete and rich cultural connotation and marketing system for college cultural and creative products. The establishment of cultural creative design workshops in colleges and universities is to protect the heritage of traditional culture, which enables traditional culture to appear in daily life in a new way, and provides opportunities and platforms for students to understand traditional culture and improve their ability of design practice. It also serves as a major contributor to the construction of campus culture and the enrichment of campus cultural spirit.

\section{References}

[1] Zhou Jun. A Design and Research of the Cultural and Creative Products of Nanjing Museum [D]. Southeast University, 2016: 9-10. (in Chinese)

[2] Zhu Peng. Research on the Innovation and Development Path of University Cultural and Creative Products [J]. Journal of Nanjing Arts Institute Fine Arts \& Design, 2018.04. (in Chinese)

[3] Wang Yamin. Accounts of the Cultural and Creative Activities of the Palace Museum [M]. Hebei University Press, 2018.12. (in Chinese)

[4] Lin Rongtai. Cultural Creativity [M]. Taiwan Xinbei. National Library of Taiwan, 2014.10. (in Chinese)

[5] Wei Ran. The status quo and analysis of college souvenir market [J]. Theoryotic Obsorvation, 2016. (in Chinese)

[6] Huang Yue, Liu Jie. Design of Traditional Cultural Creative Products in Colleges and Universities [J]. Packaging Engineering, 2018(18). (in Chinese) 